\title{
PENCEGAHAN DAN PENGENDALIAN DIABETES MELITUS MELALUI OLAHRAGA
}

Oleh: Sigit Nugroho

\section{Dosen Jurusan Pendidikan Kesehatan dan Rekreasi FIK UNY}

Abstrak

Diabetes melitus adalah suatu sindroma yang ditandai dengan hiperglikemia kronik dan gangguan metabolisme karbohidrat, lemak dan protein yang berhubungan dengan defisiensi absolut atau relatif pada sekresi insulin dan aksi insulin. Ada empat syarat untuk mencegah dan mengendalikan diabetes melitus yaitu edukasi, perencanaan makan, olahraga dan intervensi farmakologis. Salah satu syarat pengelolaan diabetes melitus yaitu dengan berolahraga. Olahraga merupakan suatu kegiatan yang murah, mudah dan dapat dikerjakan setiap waktu serta aman selama dipersiapkan dan dimonitor dengan baik. Olahraga bermanfaat untuk menurunkan berat badan dan memperbaiki sensitivitas terhadap insulin, sehingga akan memperbaiki kendali glukosa darah. Sekalipun tidak terjadi penurunan berat badan, peningkatan sensitivitas insulin serta penurunan kadar glukosa darah tetap terjadi. Walaupun demikian, penderita diabetes melitus yang mengalami penurunan berat badan akan mendapat manfaat yang lebih besar. Sebelum melakukan olahraga, penderita diabetes harus memperhatikan persiapanpersiapan khusus, memilih jenis-jenis olahraga yang cocok, berserta intensitas dan frekuensinya yang tepat sehingga olahraga tersebut dapat memberikan manfaat yang lebih besar, aman, nyaman dan memperbaiki kualitas hidup penderita diabetes melitus.

Kata Kunci: diabetes melitus dan olahraga

Banyak orang yang masih mengangap penyakit diabetes merupakan penyakit orang tua atau penyakit yang hanya timbul karena faktor keturunan. Padahal, setiap orang dapat mengidap diabetes, baik tua, muda, maupun anak-anak. Menurut data WHO, Indonesia menempati urutan ke-4 terbesar dalam jumlah penderita diabetes melitus di dunia. Pada tahun 2000 terdapat sekitar 5,6 juta penduduk Indonesia yang mengidap diabetes. Pada tahun 2006 diperkirakan jumlah penderita diabetes di Indonesia meningkat tajam menjadi 14 juta orang, dimana baru $50 \%$ yang sadar mengidapnya dan diantara mereka baru sekitar 30 $\%$ yang datang berobat teratur. Diabetes melitus adalah penyakit yang serius dan progresif, dengan jumlah penderita yang semakin banyak di Indonesia, yaitu kira-kira 14,7 \% penduduk perkotaan, dan 7,2 \% di pedesaan. Hampir sebagian besar diabetes tersebut tergolong diabetes tipe 2 yang disebabkan faktor keturunan, tetapi faktor keturunan saja tidak cukup untuk menyebabkan seseorang terkena diabetes karena risikonya hanya sebesar $5 \%$. (http://www.naturindonesia.com).

Penyakit kencing manis atau diabetes tergantung pada jenis diabetes yang diderita. Diabetes yang umum terjadi dan diderita banyak orang yaitu diabetes tipe 1 dan diabetes tipe 2. Perbedaannya adalah jika diabetes tipe 1 karena masalah fungsi organ pankreas tidak dapat 


\section{MEDIKORA Vol. IX, No 1 Oktober 2012}

menghasilkan insulin, sedangkan diabetes tipe 2 karena masalah jumlah insulin yang kurang dan bukan karena pankreas tidak bisa berfungsi baik. Diabetes tipe 2 lebih sering terjadi pada orang yang mengalami obesitas atau kegemukan akibat gaya hidup yang dijalaninya, dimana penyebabnya adalah kurangnya sekresi insulin pankreas dan adanya resistensi tubuh terhadap insulin. Banyak penderita diabetes tidak menyadari dirinya mengidap penyakit, hal ini disebabkan karena minimnya informasi di masyarakat tentang diabetes terutama gejalagejalanya.

Gejala diabetes awalnya berhubungan dengan efek langsung dari kadar gula darah yang tinggi. Kadar gula darah yang tinggi sampai diatas 160-180 mg/dL, maka glukosa akan dikeluarkan melalui air kemih, jika kadarnya lebih tinggi lagi, ginjal akan membuang air tambahan untuk mengencerkan sejumlah besar glukosa yang hilang. Gejala atau ciri awal penderita diabetes sering disebut dengan triaspoli (poliuri, polidipsi dan polifagi). Poliuri terjadi jika ginjal menghasilkan air kemih dalam jumlah yang berlebihan, maka penderita sering berkemih dalam jumlah yang banyak. Polidipsi terjadi akibat adanya poliuri, karena penderita merasakan haus yang berlebihan sehingga banyak minum. Polifagi terjadi karena sejumlah besar kalori hilang ke dalam air kemih, sehingga penderita mengalami penurunan berat badan, untuk itu penderita seringkali merasakan lapar yang luar biasa sehingga banyak makan. Gejala lainnya adalah pandangan kabur, pusing, mual dan berkurangnya ketahanan tubuh selama melakukan olahraga (http://medicastore.com).

Menurut Theresa C Tjindrawati dan S. Wibisono (2004: 72) salah satu pilar pengelolaan diabetes mellitus yaitu dengan berolahraga, olahraga merupakan suatu kegiatan yang murah, mudah dan dapat dikerjakan setiap waktu serta aman selama dipersiapkan dan dimonitir dengan baik, sehingga timbul perasaan sehat dan nyaman pada penderita diabetes dan dapat meningkatkan kualitas hidup para penderita diabetes. Olahraga bagi penderita diabetes atau kencing manis tidak berbeda dengan yang untuk orang sehat. Olahraga dapat membantu seseorang dalam mengontrol, menurunkan berat badan pada seorang yang kelebihan berat badan dan juga dapat membantu menurunkan kadar gula darah. Olahraga untuk penderita diabetes sangatlah penting sekali, untuk menurunkan kadar insulin di dalam tubuh, juga sangat bagus untuk mengurangi tekanan darah dan berat badan. Penderita diabetes melitus yang sering melakukan olahraga rutin, lebih jarang terkena serangan jantung dan penyakit stroke, dibandingkan dengan penderita diabetes melitus yang tidak pernah melakukan olahraga secara teratur. Olahraga dapat membantu mengontrol kadar gula darah karena pada saat olahraga, sel-sel di otot bekerja lebih keras sehingga lebih membutuhkan gula dan oksigen untuk dibakar menjadi tenaga dibandingkan saat beristirahat. Olahraga juga 


\section{MEDIKORA Vol. IX, No 1 Oktober 2012}

membantu kerja dari insulin karena gula dalam darah dialirkan ke dalam sel otot untuk dirubah menjadi energi sehingga otomatis kadar gula didalam darah akan menurun sehingga akan meringankan kerja dari insulin.

\section{DIABETES MELITUS (DM)}

\section{Pengertian Diabetes Melitus}

Setiap makanan yang disantap akan diubah menjadi energi oleh tubuh. Makanan di dalam lambung dan usus, akan diuraikan menjadi beberapa elemen dasarnya, termasuk salah satu jenis gula, yaitu glukosa. Gula menyebabkan pankreas akan menghasilkan insulin, yang membantu mengalirkan gula ke dalam sel-sel tubuh sehingga gula dapat diserap dengan baik dalam tubuh dan dibakar untuk menghasilkan energi. Seseorang yang menderita diabetes maka pankreas tidak dapat menghasilkan cukup insulin untuk menyerap gula yang diperoleh dari makanan, sehingga kadar gula dalam darah menjadi tinggi akibat timbunan gula dari makanan yang tidak dapat diserap dengan baik dan dibakar menjadi energi. Penyebab lain adalah insulin yang cacat atau tubuh tidak dapat memanfaatkan insulin dengan baik (http://sharehealthincome.weebly.com).

Insulin adalah hormon yang dihasilkan pankreas, sebuah organ di samping lambung. Hormon ini melekatkan dirinya pada reseptor-reseptor yang ada pada dinding sel. Insulin bertugas untuk membuka reseptor pada dinding sel agar glukosa memasuki sel. Sel-sel tersebut mengubah glukosa menjadi energi yang diperlukan tubuh untuk melakukan aktivitas. Insulin membantu menyalurkan gula ke dalam sel agar diubah menjadi energi. Jika jumlah insulin tidak cukup, maka terjadi penimbunan gula dalam darah sehingga menyebabkan diabetes (http://diabetesindo.weebly.com).

Diabetes melitus berasal dari Bahasa Yunani $\delta l \alpha \beta \alpha i v \varepsilon l v$, diabainein, "tembus" atau "pancuran air", dan dari Bahasa Latin mellitus, "rasa manis" yang umum dikenal sebagai kencing manis. Kencing manis adalah penyakit yang ditandai dengan hiperglisemia (peningkatan kadar gula darah) yang terus-menerus dan bervariasi, terutama setelah makan. Pengertian dari Bahasa Yunani dan Latin menggambarkan diabetes dengan tepat, karena air melewati tubuh penderita diabetes seolah-olah dialirkan dari mulut lewat saluran kemih dan langsung keluar dari tubuh. Air seni diabetisi (pengidap diabetes) rasanya manis karena mengandung gula. Salah satu tes untuk diabetes yaitu dengan menuangkan air seni sang pasien ke dekat sarang semut, jika serangga itu mengerumuni air seni, hal ini menunjukkan adanya gula. (http://xamthoneplus.aparsuparjo.com). 


\section{MEDIKORA Vol. IX, No 1 Oktober 2012}

Diabetes Millitus (DM) atau kencing manis adalah penyakit dimana kadar gula dalam darah meningkat karena terganggunya hormon insulin. Menurut Mohamed Yosri Mohamed Yong (2011: 1) kencing manis atau diabetes melitus merupakan keadaan di mana terdapat glukosa di dalam urine seseorang, yang disebabkan glukosa (gula) dalam darah tidak dapat dimasukan dalam sel karena kekurangan penghasilan insulin, kurang kuantitas dan kurang kualitasnya.

\section{Gejala/Tanda Diabetes Melitus}

Tanda-tanda penyakit diabetes diantaranya cepat haus, sering buang air kecil, lekas lelah, dan berat badan menurun meskipun nafsu makan tetap tinggi. Dalam kondisi yang lebih parah, gejala yang ditimbulkan dapat berupa pandangan mata kabur, bila ada luka sulit untuk sembuh dan impotensi pada pria. Menurut Emma S. Wirakusumah (2000: 4) gejala khas yang sering timbul dan dikeluhkan oleh penderita diabetes melitus adalah:

a. Trias poli yaitu:

1). Poliuria, yaitu banyaknya kencing akibat hiperglikemia, maka terjadilah penambahan bentuk air kemih dengan jelas penarikan cairan ke sel-sel tubuh.

2). Polidipsia, yaitu banyak minum. Sebenarnya keluhan ini merupakan reaksi tubuh akan adanya poliuria yang menyebabkan kekurangan cadangan air tubuh.

3). Poliphagia, yaitu nafsu makan bertambah, karena karbohidrat tidak dapat digunakan karena jumlah insulin tidak dapat menjamin proses metabolisme glukosa.

b. Lemas, ini akibat karbohidrat yang keluarnya bersama urine maka tubuh kekurangan kalori.

c. Berat badan menurun, oleh karena gula yang ada pada darah tidak dapat dioksidasi, maka terpaksa menghasilkan tenaga, sehingga tubuh kehilangan lemak yang mengakibatkan penderita menjadi kurus.

d. Polineuritis, yaitu rasa gatal-gatal seluruh tubuh, seperti diketahui untuk metabolisme karbohidrat diperlukan vitamin B1, dimana vitamin B1 digunakan sebagai co-enzim, karena kadar gula yang meningkat.

e. Hyperglikemia, yaitu kadar gula tubuh yang meningkat karena tubuh kekurangan insulin, sehingga glukosa dapat dirubah menjadi glikogen.

Gejala-gejala yang bisa menunjukkan seseorang menderita diabetes atau tidak, adalah dengan melakukan pengecekan. Pengecekan bisa dilakukan dengan tes darah, tes urine dan glukometer, untuk mengetahui menderita diabetes atau tidak salah satu dengan 


\section{MEDIKORA Vol. IX, No 1 Oktober 2012}

pengecekan tes darah dapat diketahui dengan melihat kadar gula darah normal pada tabel 1 berikut:

Tabel 1. Kadar gula darah normal

\begin{tabular}{|l|l|}
\hline \multicolumn{1}{|c|}{ Kadar gula setelah puasa } & \multicolumn{1}{|c|}{ Kadar gula 2 jam setelah makan } \\
\hline Normal $:<100 \mathrm{mg} / \mathrm{dl}$ & Normal $:<140 \mathrm{mg} / \mathrm{dl}$ \\
Pradiabetes $: \quad 100-126 \mathrm{mg} / \mathrm{dl}$ & Pradiabetes $: \quad 140-200 \mathrm{mg} / \mathrm{dl}$ \\
Diabetes $:>126 \mathrm{mg} / \mathrm{dl}$ & Diabetes $:>200 \mathrm{mg} / \mathrm{dl}$ \\
\hline
\end{tabular}

Sumber: http://kumpulan.info/271-diabetes-penyakit-gula.html

\section{Jenis-Jenis Diabetes Melitus}

Menurut Nia Daniati (2008: 3) penyakit diabetes melitus dibagi atas :

a. Diabetes tipe Juvenil (juvenile type), yaitu diabetes yang biasanya dijumpai pada anakanak atau dewasa muda. Tipe ini menyebabkan kelenjar pankreas tidak mampu membentuk hormon insulin, sehingga mengobatinya diperlukan suntikan hormon insulin dari luar.

b. Diabetes tipe dewasa (adult type), yaitu diabetes yang biasanya dijumpai pada orang dewasa. Diabetes tipe dewasa ini kelenjar pankreas masih mampu membentuk hormon insulin, hanya saja jumlah hormon tidak cukup untuk memenuhi kebutuhan yang diperlukan tubuh.

Menurut Mohamed Yosri Mohamed Yong (2011: 3), jenis kencing manis (diabetes melitus) dibagi menjadi beberapa jenis yaitu:

a. Diabetes tergantung insulin/jenis pertama (Type 1 diabetes)

Diabetes jenis pertama (Type 1 diabetes) juga dikenali sebagai diabetes tergantung insulin (IDDM - 'Insulin Dependent Diabetes Mellitus') atau diabetes awal remaja. Pengidap diabetes tergantung insulin dapat hidup normal apabila menerima suntikan insulin, tetapi akan berbahaya jika tidak mendapat suntikan insulin dalam waktu yang singkat, karena penguraian sumber bahan tenaga lain oleh badan seperti lemak untuk mengantikan tenaga dari glukusa. Penguraian sumber bahan tenaga akan menghasilkan bahan sampingan seperti keton yang menyebabkan keadaan hiperglisemia (hyperglycemia). Keton merupakan molekul asid yang mampu menyebabkan kegagalan metabolisme dan sel tubuh gagal berfungsi. Keadaan ini akan mengakibatkan pengidap kencing manis menjadi koma dan menemui maut jika tidak dirawat. 


\section{MEDIKORA Vol. IX, No 1 Oktober 2012}

Diabetes jenis pertama terbentuk apabila sistem imunisasi badan memusnahkan sel beta kelenjar pankreas, satu-satunya jenis sel yang menghasilkan hormon insulin yang digunakan untuk membantu glukosa masuk sel yang digunakan untuk tenaga. Diabetes ini sering dijumpai pada golongan anak-anak dan remaja yang memerlukan beberapa suntikan insulin setiap hari, atau menggunakan cadangan insulin, untuk terus hidup. Penderita yang berisiko mengidap kencing manis jenis I adalah serangan sistem imunisasi sendiri (autoimmune), genetik, dan alam sekeliling. Pengidap diabetes tergantung insulin perlu disuntik sebelum makan dan kadangkala insulin tambahan perlu disuntik pada waktu malam sebelum tidur. Kekurangan dan kelebihan kadar gula dalam darah dapat menyebabkan hal buruk terjadi pada pederita diabetes, karena terlalu banyak insulin diambil atau disuntik, keadaannya bisa hipoglisemia disebabkan kekurangan glukosa.

b. Diabetes bebas insulin/jenis kedua. (Type II diabetes)

Diabetes bebas insulin (jenis kedua) biasanya disebut NIDDM (Non-Insulin Dependent Diabetes Mellitus) juga dikenali sebagai diabetes peringkat permulaan dewasa. Diabetes bebas insulin (jenis kedua) biasanya bermula dengan ketahanan insulin, dimana badan tidak menggunakan insulin dengan baik. Apabila keperluan menggunakan insulin meningkat, kelenjar pankreas tidak lagi mampu mengeluarkan insulin pada kadar mencukupi. Diabetes bebas insulin (jenis kedua) biasanya seiring dengan faktor usia lanjut, gemuk (obesity), keturunan dan kurang berolahraga. Perbedaan dari dua jenis diabetes dapat dijelaskan pada tabel 2 dibawah ini:

Tabel 2. Perbedaan diabetes millitus tipe 1 dan tipe 2

\begin{tabular}{|c|l|l|}
\hline \multicolumn{1}{|c|}{ Aspek } & \multicolumn{1}{|c|}{ Diabetes Mellitus tipe 1 } & \multicolumn{1}{c|}{ Diabetes Mellitus tipe 2 } \\
\hline Patofisiologi & $\begin{array}{l}\text { Penderita menghasilkan sedikit } \\
\text { insulin atau sama sekali tidak } \\
\text { menghasilkan insulin }\end{array}$ & $\begin{array}{l}\text { Pankreas tetap menghasilkan } \\
\text { insulin, kadarnya lebih tinggi } \\
\text { dari normal, tetapi tubuh } \\
\text { membentuk kekebalan } \\
\text { terhadap efeknya, sehingga } \\
\text { terjadi kekurangan insulin }\end{array}$ \\
\hline
\end{tabular}




\begin{tabular}{|c|c|c|}
\hline & & relatif \\
\hline Onset & $\begin{array}{l}\text { Umumnya terjadi sebelum usia } 30 \\
\text { tahun, yaitu anak-anak dan remaja. }\end{array}$ & $\begin{array}{l}\text { Bisa terjadi pada anak-anak } \\
\text { dan dewasa, tetapi biasanya } \\
\text { terjadi setelah usia } 30 \text { tahun }\end{array}$ \\
\hline Faktor resiko & $\begin{array}{l}\text { Faktor lingkungan (berupa infeksi } \\
\text { virus atau faktor gizi pada masa } \\
\text { kanak-kanak atau dewasa awal) } \\
\text { menyebabkan sistem kekebalan } \\
\text { menghancurkan sel penghasil insulin } \\
\text { di pankreas dan kecenderungan } \\
\text { genetik. }\end{array}$ & $\begin{array}{l}\text { Faktor resiko untuk diabetes } \\
\text { tipe } 2 \text { adalah obesitas dimana } \\
\text { sekitar } 80-90 \% \text { penderita } \\
\text { mengalami obesitas. }\end{array}$ \\
\hline
\end{tabular}

Sumber: http: //www.naturindonesia.com

c. Diabetes ketika Hamil (Gestational diabetes)

Diabetes ketika hamil merupakan sejenis gangguan glukusa yang dikenal pada sebagian wanita ketika mengandung. Diabetes ketika hamil sering dijumpai di kalangan orang Amerika keturunan Afrika, Hispanik/Latin, dan Red Indian. Diabetes ketika hamil juga biasa didapati dikalangan wanita kuat makan, atau wanita yang dari keturunan pengidap diabetes. Ketika mengandung, diabetes ketika hamil memerlukan penjegahan untuk menurunkan kadar gula dalam darah agar tidak menular kepada kandungan. Setelah mengandung, kebanyakan wanita $90 \%$ hingga $95 \%$ kembali sembuh. Sebagian kecil pula antara $5 \%$ hingga $10 \%$ didapati mengidap diabetes bebas insulin (jenis kedua). Wanita yang mengalami diabetes ketika hamil mempunyai risiko $20 \%$ hingga $50 \%$ mengidap diabetes dalam waktu 5 hingga 10 tahun. Diabetes ketika hamil juga meningkatkan lagi risiko bayi mempunyai kadar bilirubin yang tinggi (demam kuning) dibanding bayi normal.

\section{Resiko dan Pencegahan Diabetes Melitus}

Resiko penderita diabetes melitus sebagian besar berasal dari keluarga atau keturunan di mana terdapat ahli-ahli yang mengidap penyakit kencing manis yang usianya diatas 40 tahun, yang mempunyai berat badan berlebihan atau gemuk mempunyai risiko yang lebih untuk mendapat kencing manis. Seseorang yang memiliki faktor resiko diabetes adalah:

1. Mereka yang memiliki riwayat keluarga penderita diabetes

2. Berusia lebih dari 45 tahun 


\section{MEDIKORA Vol. IX, No 1 Oktober 2012}

3. Memiliki riwayat penyakit tekanan darah tinggi, kolesterol tinggi dan trigliserida tinggi

4. Pernah melahirkan bayi dengan berat badan $>4000$ gr

Menurut Kushartanti (2005) yang dikutip oleh Nia Daniati (2008: 5) kegiatan untuk mencapai program pencegahan penyakit pada penderita diabetes melitus yaitu :

1. Diet yaitu menkonsumsi makanan yang berserat tinggi, rendah gula, dan banyak air putih.

2. Olahraga yang teratur.

a. Olahraga intermiten $(1-3-1)$ untuk mengelola kadar glukosa darah dan memperbaiki propel lipid. Perbandingan irama gerak 1 (anerob), 3 (aerob), dan 1 (anaerob)

b. Stretching dan loosening untuk kelenturan sendi dan lancarnya aliran darah tepi.

c. Meditasi dan Senam Pernafasan.

Olahraga yang dianjurkan untuk penderita diabetes adalah olahraga aerobic low impact dan rithmis seperti senam, jogging, berenang dan naik sepeda. Porsi latihan juga harus diperhatikan, latihan yang berlebihan akan merugikan kesehatan, sedangkan latihan yang terlalu sedikit tidak begitu bermanfaat. Penentuan porsi latihan tersebut harus memperhatikan intensitas latihan, lama latihan dan frekuensi latihan.

\section{OLAHRAGA DAN DIABETES MELITUS}

\section{Manfaat Olahraga}

Olahraga merupakan aktivitas yang sangat penting untuk mempertahankan kebugaran seseorang dan merupakan salah satu metode penting untuk mereduksi stress. Olahraga juga merupakan suatu perilaku aktif yang menggiatkan metabolisme dan mempengaruhi fungsi kelenjar di dalam tubuh untuk memproduksi sistem kekebalan tubuh dalam upaya mempertahankan tubuh dari gangguan penyakit serta stress. (http://carapedia.com).

Olahraga adalah serangkaian gerak raga yang teratur dan terencana untuk memelihara gerak (mempertahankan hidup) dan meningkatkan kemampuan gerak (meningkatkan kualitas hidup). Olahraga seperti halnya makan merupakan kebutuhan hidup yang sifatnya periodik, artinya Olahraga sebagai alat untuk memelihara dan membina kesehatan, tidak dapat ditinggalkan. Olahraga merupakan alat untuk merangsang pertumbuhan dan perkembangan jasmani, rohani dan sosial (Edwin Syarief, 2011: 1).

Salah satu cara yang paling murah untuk sehat dan untuk menjaga badan agar tetap bugar yaitu dengan Olahraga, karena olahraga dapat dilaksanakan kapanpun dan 


\section{MEDIKORA Vol. IX, No 1 Oktober 2012}

dimanapun baik pagi, siang maupun malam sesuai dengan keinginan. Olahraga dapat menjaga dari berbagai penyakit seperti tekanan darah tinggi, diabetes, penyakit jantung dan osteoporosis, apabila sudah mengidap penyakit tersebut, berolahraga secara teratur akan membantu mengelolanya sehingga tidak berkembang membahayakan. Olahraga bahkan mengurangi risiko stroke, sakit punggung bawah (LBP), kanker usus besar, kanker payudara, kanker paru dan endometrium.

Sebuah riset menemukan bahwa pria yang berolah raga secara teratur dengan intensitas sedang dan berat lebih kecil kemungkinannya terkena stroke dibandingkan pria yang kurang aktif. Riset tersebut meneliti 3.298 orang dengan usia rata-rata 69 tahun yang tinggal di Manhattan Utara, New York. Pria yang berolah raga $63 \%$ lebih kecil kemungkinannya terkena stroke dibandingkan mereka yang tidak berolah raga (Neurology, 24 November 2009). Namun, olahraga tampaknya tidak memberikan dampak yang sama bagi kaum wanita (http://majalahkesehatan.com).

Menurut Bortz (1983) yang dikutip Hardianto Wibowo (2003: 247) tidak ada obat yang sekarang atau masa depan akan dipakai, yang menjanjikan dengan pasti akan memberikan dan mempertahankan kesehatan lebih baik daripada kebiasaan hidup yang senantiasa berolahraga. Berolahraga dapat memberikan kehidupan yang sehat dan nyaman bila diikuti dan dilakukan dengan teratur, karena dengan berolahraga menyebabkan otototot menjadi kuat, jantung menjadi sehat, tekanan darah menjadi normal, kadar gula dapat terkontrol dan berat badan menjadi seimbang yang kesemuanya ini akan membuat tubuh sehat dan nyaman.

\section{Jenis Olahraga Diabetes}

Mengelola penyakit diabetes sebenarnya mudah asal penderita bisa mendisiplinkan diri, melakukan olahraga secara teratur, menuruti saran dokter, dan tidak mudah patah semangat. Olahraga yang teratur sangat baik sekali pengaruhnya terhadap kesehatan tubuh dan dapat mengendalikan risiko diabetes. Bagi penderita diabetes, olahraga sangat banyak sekali manfaat yang diperoleh diantaranya:

a. Membakar kalori dan mengurangi lemak tubuh sehingga meningkatkan kemampuan metabolisme sel dalam menyerap dan menyimpan glukosa.

b. Meningkatkan sirkulasi darah, terutama pada kaki dan tangan, di mana biasanya penderita diabetes memiliki masalah. 


\section{MEDIKORA Vol. IX, No 1 Oktober 2012}

c. Mengurangi stress yang sering menjadi pemicu kenaikan glukosa darah penderita diabetes yang rajin berolah raga dapat melepaskan diri dari ketergantungan pada obat. (http://blog-penyakit.blogspot.com)

Penderita diabetes melitus sering disarankan untuk berolahraga. Namun, tidak serta merta olahraga bisa menolong penderita diabetes. Dalam kondisi tertentu, penderita diabetes juga dilarang melakukan sembarang olahraga. Khususnya, yang mengundang risiko cedera seperti pendarahan retina hingga kematian. Menurut Irfanuddin (2011: 1) penderita diabetes melitus memerlukan sikap kehati-hatian untuk memilih olahraga yang sesuai dan harus menghindari olahraga yang mengundang risiko cedera. Olahraga yang disarankan bagi penderita diabetes adalah jogging, jalan kaki, senam, dan renang. Penderita diabetes juga disarankan melakukan olahraga ringan seperti senam kaki atau senam khusus yang diberi nama senam sepuluh menit. Jenis olahraga bagi penderita diabetes dipilih yang memiliki nilai aerobik tinggi, seperti jalan cepat, lari (joging), senam aerobik, renang, dan bersepeda. Jenis olahraga lainnya, tenis lapangan, tenis meja, bahkan sepakbola, boleh dilakukan asal dengan perhatian ekstra dan disertai dengan frekuensi, intensitas, dan durasi (FID) yang tepat.

Menurut Theresa C Tjindrawati dan S. Wibisono (2004: 75) penderita diabetes yang mengalami kehilangan sensasi protektif olahraganya harus disesuiakan. Sensasi protektif adalah sensitif rasa yang mulai berkurang biasanya terjadi pada kaki yang disebabkan oleh neuropati perifer. Aktivitas fisik yang dikontraindikasikan dan yang direkomendasikan untuk pasien yang kehilangan sensasi protektif pada kaki dapat di lihat pada tabel 3 berikut:

Tabel 3. Olahraga pada penderita diabetis yang kehilangan sensasi protektif

\begin{tabular}{|l|l|}
\hline Olahraga yang dikontraindikasikan & Olahraga yang direkomendasikan \\
\hline Treadmill & Berenang, Tai Chi \\
Jogging & Bersepeda \\
Step exercises & Mendayung \\
& $\begin{array}{l}\text { Olahraga dengan kursi, olahraga dengan } \\
\text { lengan dan olahraga lainnya yang tidak } \\
\text { menahan beban }\end{array}$ \\
\hline
\end{tabular}

Pada prinsipnya olahraga bagi penderita diabetes tidak berbeda dengan orang yang sehat. Olahraga itu terutama untuk membakar kalori tubuh, sehingga glukosa darah bisa 


\section{MEDIKORA Vol. IX, No 1 Oktober 2012}

terpakai untuk energi sehingga kadar gulanya bisa turun. Menurut Hario Tilarso (1999) yang dikutip Nanny Selamihardja dan I Gede Agung Yudana (2008: 4) hanya dengan latihan olahraga penderita diabetes sanggup hidup seperti orang-orang sehat tanpa obat. Orang-orang yang tidak tergantung insulin, bisa turun kadar gulanya hanya dengan exercise. Exercise atau berolahraga menyebabkan timbunan kolesterol di pembuluh darah akan berkurang, sehingga risiko terkena penyakit jantung menurun.

Olahraga bagi penderita diabetes pada prinsipnya tidak berbeda dengan yang diterapkan untuk orang sehat. Frekuensi berolah raga adalah $3-5$ kali seminggu. Intensitasnya berkisar $60-75 \%$ dari denyut nadi maksimal. (DNM $=220-$ Umur). Durasinya kira-kira 60 menit setiap kali berolahraga pada zone latihan. Penderita diabetes yang berbadan gemuk, durasinya bisa ditambah, sekitar 90 menit. Penambahan lama latihan dapat menyebabkan berkurangnya gula darah dan terbakarnya lemak tubuh. Klasifikasi intensitas olahraga, berdasarkan pada olahraga selama 60 menit dapat dilihat pada tabel 4 berikut:

Tabel 4. Klasifikasi intensitas olahraga, berdasarkan pada olahraga selama 60 menit

\begin{tabular}{|c|l|c|c|}
\hline No & \multicolumn{1}{|c|}{ Intensitas } & $\mathrm{VO}_{2}$ Max & Denyut Jantung Maksimal (\%) \\
\hline 1 & Sangat ringan & $<20$ & $<35$ \\
\hline 2 & Ringan & $20-39$ & $35-54$ \\
\hline 3 & Sedang & $40-59$ & $70-69$ \\
\hline 4 & Berat & $60-84$ & $>90$ \\
\hline 5 & Sangat berat & $>85$ & 100 \\
\hline 6 & Maksimal* & 100 & \\
\hline
\end{tabular}

*Nilai maksimal merupakan nilai yang dapat dicapai orang dewasa normal selama olahraga maksimal (sumber: Theresa C Tjindrawati dan S. Wibisono, 2004: 74)

Menurut Theresa C Tjindrawati dan S. Wibisono (2004: 72) selama olahraga konsumsi oksigen seluruh tubuh dapat meningkat sampai 20 kali lipat, dan mungkin dapat meningkat lebih tinggi lagi pada otot-otot yang sedang bekerja. Untuk memenuhi kebutuhan energi pada saat olahraga, cadangan glikogen dan trigliserida jaringan lemak, dan glukosa dilepaskan dari hati. Untuk mempertahankan fungsi sistem saraf saraf pusat, kadar glukosa darah harus sungguh diperhatikan selama olahraga. Pengaturan metabolik yang mempetahankan normoglikemia selama olahraga terutama melalui pengaturan hormon. Penurunan insulin plasma dan tersedianya glukagon tampaknya diperlukan untuk 


\section{MEDIKORA Vol. IX, No 1 Oktober 2012}

peningkatan awal produksi glukosa hepatik selama olahraga dan pada olahraga dalam jangka waktu yang lama, peningkatan glukagon plasma dan katekolamin tampaknya memegang peranan penting.

Kadar gula darah penderita saat melakukan olahraga harus berada pada kisaran 100 - $300 \mathrm{mg} / \mathrm{dl}$, lebih dari $300 \mathrm{mg} / \mathrm{dl}$ dikhawatirkan terjadi ketosis (kelebihan keton dalam jaringan). Penderita dengan kadar gula yang terlalu rendah juga dilarang melakukan latihan, karena ditakutkan apabila kadar gulanya sudah normal lalu melakukan olahraga akan terjadi hipoglikemia. Sebelum melakukan olahraga, pastikan penderita memeriksakan diri ke dokter untuk mengetahui kondisi kesehatannya secara menyeluruh. Apabila sudah merekomendasikan untuk melakukan olahrga, maka ada beberapa tips yang bisa dilakukan penderita diabetes saat olahraga yaitu:

a. Jika mengalami sakit misalnya merasa lemah, peningkatan denyut jantung dan berkeringat lebih dari biasanya selama berolahraga maka segera berhenti, untuk menghindari kerusakan jaringan dan juga sendi.

b. Jangan lupa untuk mencatat kadar gula darah sebelum dan setelah olahraga.

c. Pastikan membawa makanan ringan yang manis disaku saat olahraga, jika merasa gula darah turun segera konsumsi.

d. Kenakan sepatu yang nyaman untuk menghindari luka atau cedera.

e. Mengonsumsi air yang cukup sebelum melakukan olahraga (http://health.detik.com).

Selain itu sebelum olahraga penderita harus mengetahui risiko-risiko dan masalahmasalah yang potensial terjadi saat olahraga. Berikut beberapa masalah risiko yang potensial saat olahraga.

1. Hiperglikemia:

a. Insufisiensi insulin, penyebabnya:

Peningkatan produksi glukosa hepatik, ketogenesis

b. Kelebihan glukosa

2. Hipoglikemia:

a. Kelebihan Insulin, penyebabnya:

1) Terlalu banyak insulis sebelum olahraga

2) Peningkatan sensitivitas insulin yang dirangsang selama olahraga

3) Peningkatan absorpsi dari tempat injeksi

4) Efek medikasi (sulfonilurea, insulin sekretagog)

b. Insufisiensi glukosa/karbohidrat, penyebabnya:

1) Olahraga spontan yang tidak direcanakan 


\section{MEDIKORA Vol. IX, No 1 Oktober 2012}

2) Kalori diet yang sangat rendah

3. Memburuknya komplikasi yang sudah ada:

a. Retinopati (belum terbukti dengan baik)

b. Proteinuria (akut)

4. Akibat/Konsekuensi komplikasi yang sudah ada sebelumnya:

a. Neuropati perifer yang menyebabkan luka di kaki (robeknya kulit, fraktur, infeksi)

b. Kelainan arteri koroner yang menyebabkan iskemi

c. Neuropati otonom yang menyebabkan aritmia

Berdasarkan risiko atau masalah yang potensial terjadi saat olahraga atau sesudahnya, maka beberapa langkah spesifik seharusnya diterapkan untuk menghindari risiko-risiko tersebut, yaitu:

1. Mengukur kadar glukosa darah sebelum, saat, dan sesudah olahraga

a. Jika kadar glukosa darah $<100 \mathrm{mg} / \mathrm{dl}$, makan snack dengan karbohidrat 15-20 gram sebelum olahraga

b. $100-250 \mathrm{mg} / \mathrm{dl}$, tidak perlu makan snack

c. $>250 \mathrm{mg} / \mathrm{dl}$, dengan keton atau $>300 \mathrm{mg} / \mathrm{dl}$ tanpa keton, tunda olahraga, serum keton harus diperiksa; hiperglikemia dan dehidrasi harus diatasi atau ditangani. Untuk menghindari hipoglikemia, jangan berolahraga saat aktivitas insulin mencapai puncaknya, berhati-hati akan efek hipoglikemi yang tertunda yang dapat terjadi 6-28 jam setelah suatu olahraga berat dan dapat terjadi meskipun kadar glukosa darah normal selama olahraga dan tidak tergantung usia atau beratnya penyakit, umumnya terjadi malam hari.

2. Menyesuaikan jumlah kalori atau asupan makanan

Makanan seharusnya telah tercerna 1-2 jam sebelum olahraga. Olahraga dalamwaktu lama atau berat, harus mulai meningkatkan asupan kalori 24 jam sebelumnya. Tambahan karbohidrat untuk olahraga spontan atau yang tidak direncanakan, 20-30 g per 30 menit olahraga.

3. Penyesuaian penggunaan insulin

Menggunakan insulin lebih dari 1 jam sebelum olahraga dengan menyuntikan insulin di bagian yang tidak berperan aktif dalam olahraga, absorpsi di abdomen adalah yang paling cepat absorpsinya dan paling dapat diandalkan.

4. Monitoring adanya luka lepuh di kaki, ulkus dan komplikasi-komplikasi, problemproblem lainya.

5. Pemeriksaan laboratorium meliputi $\mathrm{HbA}_{1 \mathrm{c}}$, profil lipid, mikroalbuminuria pada urin, 


\section{MEDIKORA Vol. IX, No 1 Oktober 2012}

EKG. (Theresa C Tjindrawati dan S. Wibisono, 2004: 77)

\section{KESIMPULAN}

Diabetes memang penyakit yang tidak bisa disembuhkan, namun dengan perawatan yang baik, setiap penderita dapat menjalani kehidupannya secara normal. Kendati tak bisa disembuhkan, penderita diabetes sebenarnya bisa hidup secara normal. Caranya dengan melakukan kontrol gula darah disertai diet dan olahraga yang teratur. Olahraga merupakan salah satu pilar dalam mencegah dan mengendalikan diabetes melitus, karena olahraga merupakan suatu kegiatan yang murah, mudah dan dapat dikerjakan setiap waktu serta aman selama dipersiapkan dan dimonitor dengan baik, sehingga timbul perasaan sehat dan nyaman pada penderita diabetes dan dapat meningkatkan kualitas hidup para penderita diabetes. Olahraga bermanfaat untuk menurunkan berat badan dan memperbaiki sensitivitas insulin, sehingga akan memperbaiki kendali glukosa darah. Dengan rajin berolahraga ditambah mengatur menu makanan serta mengontrol kadar gula darah secara teratur, komplikasi akibat diabetes dapat dihindari.

\section{DAFTAR PUSTAKA}

Emma S. Wirakusumah (2000). Tetap Bugar di Usia Lanjut. Jakarta: Trubus Agriwidya

Edwin Syarief (2011: 1). Pengertian Olahraga. Dalam http://edwinsyarief.blogspot.com /2011/05/pengertian-olahraga.html

http://blog-penyakit.blogspot.com/2012/07/tips-atasi-diabetes-dengan-olahraga.html

http://carapedia.com/pengertian_definisi_olahraga_info2059.html

http://diabetesindo.weebly.com/pengertian-diabetes.html

http://health.detik.com/read/2012/07/03/093056/1956246/763/ini-alasan-penderita-diabetesperlu-olahraga

http://kumpulan.info/271-diabetes-penyakit-gula.html

http://majalahkesehatan.com/7-manfaat-berolahraga/

http://medicastore.com/diabetes/gejala_diabetes_mellitus.php

http://sharehealthincome.weebly.com/l/category/usus/l.html

http://www.naturindonesia.com/2012/05/-sebaran-jenis-penderita-diabetes 
MEDIKORA Vol. IX, No 1 Oktober 2012

http://xamthoneplus.aparsuparjo.com/atikel/diabetessipenyakit-gula-madu/

Hardianto Wibowo (2003). Lanjut Usia dan Olahraga. Dalam bukunya Harsuki yang berjudul Perkembangan Olahraga Terkini Kajian Para Pakar. Jakarta: PT. Raja Grafindo Persada

Irfanuddin (2008: 1). Olahraga untuk Penderita Diabetes Mellitus. http://sehatdiabetes. wordpress.com/2011/11/18/olahraga-untuk-penderita-diabetes-mellitus/

Mohamed Yosri Mohamed Yong (2011). Pengertian dan Jenis Diabetes Melitus. Dalam http://www.geocities.com

Nanny Selamihardja dan I Gede Agung Yudana (2008). Diet dan Olahraga Bagi Penderita Diabetes. http://klipingut.wordpress.com/2008/03/11

Nia Daniati (2008). Pencegahan terhadap Jenis-Jenis Penderita Diabetes Melitus. Dalam http://www.jurkesgi.com/niadm.htm

Theresa C Tjindrawati dan S. Wibisono (2004). "Olahraga dan Diabetes Melitus" (DEXA media majalah kedokteran dan farmasi, nomor: 2, Volume 17, 2004). Jakarta: Fatmawati 